\title{
Opodatkowanie spółki europejskiej a koncepcja Wspólnej Korporacyjnej Podstawy Opodatkowania (CCCTB)
}

1. Tendencje w gospodarce światowej sprzyjają powstawaniu i funkcjonowaniu holdingów. Szczególnie dotyczy to holdingów działających transgranicznie. Jednak instytucja holdingu nie została unormowana w przepisach prawnych. Również w aspekcie podatkowym unormowania są niejednolite, a przede wszystkim nie zaspokajają oczekiwań samych zainteresowanych. Lukę tę wypełniła powołana instytucja, jaką jest spółka europejska.

Spółka europejska (łac. societas europaea, ang. European Public Limited-Liability Company) - zwana dalej SE - jest ponadnarodową formą spółki uregulowaną w prawie wspólnotowym ${ }^{1}$. Ponadto w prawie polskim również uregulowana jest problematyka $\mathrm{SE}^{2}$. SE jest odmianą europejskiej spółki akcyjnej³. Spółka akcyjna najbardziej odpowiada potrzebom podmiotów prowadzących transgraniczną działalność gospodarczą z punktu widzenia finansowania i zarządzania ${ }^{4}$. Nie stanowi to przeszkody, żeby z tej regulacji skorzystali również mali i średni przedsiębiorcy, jeżeli spełnią warunki formalne utworzenia SE.

Trzeba jednocześnie zwrócić uwagę, że SE posiada cechy normatywne i strukturalne, które odróżniają ją od spółki akcyjnej (podlegającej prawu krajowemu) i determinujące jej ponadnarodowy charakter ${ }^{5}$.

SE posiada osobowość prawną, a zatem jest osobą prawną, będącą podmiotem praw i obowiązków, i może we własnym imieniu nabywać prawa, w tym

* Dr Dominik Gajewski - Wydział Prawa i Administracji, Wyższa Szkoła Finansów i Zarządzania w Warszawie.

${ }^{1}$ Rozporządzenie Rady (WE) nr 2157/2001 z dnia 8 października 2001 r. w sprawie statutu spółki europejskiej (dalej: rozp. o SE) oraz dyrektywa 2001/86/WE uzupełniająca statut spółki europejskiej w odniesieniu do zaangażowania pracowników (obydwa akty opublikowane zostały w Dz. Urz. UE L 294 z 10 listopada 2001 r.). Weszły w życie 8 października 2004 r.

${ }^{2}$ Ustawa z 4 marca 2005 r. o europejskim zgrupowaniu gospodarczym i spółce europejskiej, Dz. U. Nr 62, poz. 551 ze zm. (dalej: ustawa o EZIG i SE).

${ }_{3}$ T. Siemiątkowski, R. Potrzeszcz, Spótka europejska w polskiej typologii spółek handlowych, cz. II, „Przegląd Prawa Handlowego” 2005, nr 12, s. 18.

${ }^{4}$ Pkt 13 preambuły do rozp. o SE.

${ }^{5}$ K. Niedzielska, Europejska spótka akcyjna, Warszawa 2005, s. 35. 
własność nieruchomości oraz inne prawa rzeczowe, zaciągać zobowiązania, pozywać i być pozwana ${ }^{6}$. SE jako spółka akcyjna posiada następujące cechy:

1) osobowość prawną ${ }^{7}$;

2) kapitał zakładowy podzielony na akcje

3) wyłączenie odpowiedzialności akcjonariuszy za zobowiązania spółki9;

4) korporacyjną strukturę organów ${ }^{10}$.

Podstawowym celem SE jest umożliwianie przedsiębiorstwom europejskim zorganizowanym w formie spółki kapitałowej (spółki akcyjnej) połączenia potencjałów gospodarczych, transgranicznej współpracy i reorganizacji ich działalności w skali całej Wspólnoty Europejskiej. Konieczne jest określenie jednolitych ram prawnych dla tych procesów. Dzięki temu zostaną zmniejszone koszty związane z problematyką prawną i podatkową. SE ma umożliwić doprowadzenie do tego, aby jednolitość ekonomiczna i jednolitość prawna przedsiębiorczości we Wspólnocie pokrywały się w jak najszerszym zakresie ${ }^{11}$.

2. Nie zostały stworzone szczególne rozwiązania mające charakter przywilejów podatkowych, które miałyby zastosowanie wyłącznie do SE. Uzasadnieniem takiego stanowiska jest stwierdzenie, że prawo podatkowe winno mieć charakter neutralny i wpływać w jak najmniejszym stopniu na decyzję o wyborze takiej lub innej formy do prowadzenia działalności gospodarczej. Ponadto, szczególne uprzywilejowanie europejskich typów spółek oznaczałoby w praktyce dyskryminację narodowych spółek akcyjnych, na co, jak się wydaje, nie zgodziłoby się żadne z państw członkowskich UE.

Co do zasady Traktat Wspólnot Europejskich (TWE) nie zawiera regulacji, które byłyby wyraźną podstawą dla harmonizacji podatków bezpośrednich. Proces harmonizacji w zakresie opodatkowania dochodów spółek spotykał się ze szczególnymi trudnościami i dokonał się jedynie w ograniczonym stopniu, na podstawie ogólnego art. 94 TWE. Widocznym efektem tego procesu było wprowadzenie do unijnego ustawodawstwa czterech podstawowych instrumentów normatywnych. Są to:

- dyrektywa Rady 90/434/WE z 23 lipca 1990 r. o wspólnym systemie podatkowym dla fuzji, podziałów, wniesienia majątku i zamiany udziałów w odniesieniu do spółek różnych państw członkowskich oraz przeniesieniu statutowej siedziby SE lub SCE (O.JL.1990.225.1);

${ }^{6}$ K. Oplustil, Spótka Europejska i Europejskie Zgrupowanie Interesów Gospodarczych - akty prawne z omówieniem, Warszawa 2005, s. 93.

7 Art. 1 ust. 3 rozp. o SE.

${ }^{8}$ Art. 1 ust. 2 zd. 1 rozp. o SE.

${ }^{9}$ Art. 1 ust. 2 zd. 2 rozp. o SE.

${ }_{10}$ Art. 38 rozp. o SE.

${ }^{11}$ K. Oplustil, Europejska Spótka Akcyjna, Warszawa 2002, s. 28. 
- dyrektywa Rady 90/435/WE z 23 lipca 1990 r. o wspólnym systemie podatkowym w odniesieniu do spółek-matek i spółek-córek różnych państw członkowskich (O.JL.1990.225.6);

- dyrektywa Rady 2003/49/WE o wspólnym systemie podatkowym dla wypłat odsetek i należności licencyjnych pomiędzy podmiotami powiązanymi (O.JL.2003.157.49);

- konwencja 90/436/WE w sprawie eliminowania podwójnego opodatkowania w przypadku korekty zysków przedsiębiorstw powiązanych (tzw. konwencja arbitrażowa).

Dwie pierwsze z wyżej wymienionych dyrektyw mają już zastosowanie do SE. Dyrektywa regulująca wypłaty odsetek i należności licencyjnych pomiędzy podmiotami powiązanymi znajduje się na końcowym etapie nowelizacji, mającej dopiero umożliwić jej zastosowanie do SE. Poza wspomnianymi regulacjami wspólnotowymi, do opodatkowania SE stosuje się te same przepisy wewnętrzne państw UE, jak do opodatkowania innych spółek kapitałowych.

Biorąc to wszystko pod uwagę, można dojść do wniosku, że obecnie na gruncie europejskiego prawa podatkowego status podatkowy SE nie odbiega znacznie od statusu każdej innej spółki podlegającej prawu dowolnego państwa członkowskiego. Warto więc zastanowić się, czy taki stan rzeczy powinien mieć miejsce, szczególnie w kontekście ich statusu podatkowego.

3. Dla SE w zakresie jej bieżącej działalności najistotniejsze znaczenie mają wewnętrzne regulacje podatkowe państwa ich siedziby statutowej. Do opodatkowania dochodu tego typu spółki, która będzie mieć swoją siedzibę w Polsce, znajdą zastosowanie przede wszystkim (obok Ordynacji podatkowej ${ }^{12}$ ), w kwestiach proceduralnych, przepisy ustawy o podatku dochodowym od osób prawnych ${ }^{13}$. Szczególną uwagę należy zwrócić na ${ }^{14}$ :

- art. 3 u.p.d.o.p., zgodnie z którym podatnicy mający siedzibę lub zarząd na terytorium Polski podlegają obowiązkowi podatkowemu od całości swoich dochodów, bez względu na miejsce ich osiągania (tzw. nieograniczony obowiązek podatkowy), a podatnicy niemający na terytorium naszego państwa siedziby lub zarządu podlegają obowiązkowi podatkowemu tylko od dochodów, które osiągają na tym terytorium;

- art. 11 u.p.d.o.p. oraz rozporządzenie Ministra Finansów z dnia 10 października 1997 r. w sprawie sposobu i trybu określania dochodów podatników $\mathrm{w}$ drodze oszacowania cen $\mathrm{w}$ transakcjach dokonywanych przez tych podatni-

${ }^{12}$ Ustawa z dnia 29 sierpnia 1997 r. Ordynacja podatkowa, t.j. Dz. U. z 2005 r. Nr 8, poz. 60 ze zm.

${ }^{13}$ Ustawa z dnia 15 lutego 1992 r. o podatku dochodowym od osób prawnych, Dz. U. z 2011 r. $\mathrm{Nr} 74$, poz. 397 ze zm. (dalej u.p.d.o.p.).

${ }^{14}$ K. Oplustil, op. cit., s. 141-142. 
ków ${ }^{15}$, regulujące przesłanki i metody szacowania dochodów podmiotów powiązanych, stosujących tzw. ceny transferowe;

- art. 20 u.p.d.o.p., który wymaga od podatników objętych nieograniczonym obowiązkiem podatkowym łączenia ich krajowych dochodów z dochodami osiągniętymi poza terytorium Polski dla potrzeb ustalenia podstawy opodatkowania oraz, w dalszej kolejności, szczegółowo reguluje możliwość i dopuszczalną wysokość odliczenia - od podatku należnego do zapłaty w Polsce - podatku już przez tych podatników zapłaconego, z określonych tytułów, za granicą.

Dla spraw z zakresu opodatkowania bieżącej działalności SE istotne znaczenie będą mieć również postanowienia zawartych przez państwo siedziby spółki międzynarodowych umów o unikaniu podwójnego opodatkowania. Trzeba bowiem pamiętać, że pomimo faktu, iż SE może działać w każdym państwie UE bez konieczności tworzenia spółek zależnych lub oddziałów, nie oznacza to wcale, że spółka tego typu nie będzie musiała płacić podatku dochodowego w państwach, w których tę działalność prowadzi, innych niż państwo jej siedziby. I tak, w przypadku gdy SE będzie podlegać w Polsce opodatkowaniu od całości swoich dochodów, ze względu na lokalizację swojej statutowej siedziby i zarządu, a w Holandii otworzy zakład produkcyjny, to - w świetle umowy o unikaniu podwójnego opodatkowania pomiędzy Polską i Holandią - w Holandii powstanie tzw. zakład tej spółki. W rezultacie dochody osiągane za pośrednictwem tego zakładu będą opodatkowane w Holandii i zwolnione z opodatkowania w Polsce. Stąd też wśród postanowień tych umów szczególnie interesujące z praktycznego punktu widzenia wydają się regulacje dotyczące opodatkowania zysków zagranicznych zakładów (zgodnie z art. 7 Umowy Modelowej OECD ${ }^{16}$ ), zysków przedsiębiorstw powiązanych (art. 9 Umowy Modelowej OECD) oraz dywidend, odsetek i należności licencyjnych (art. 10, 11, 12 Umowy Modelowej OECD).

Nie należy wreszcie lekceważyć roli, jaką w zakresie problematyki opodatkowania bieżących dochodów SE mogą odgrywać wskazane na początku tego rozdziału dyrektywy wspólnotowe z zakresu podatków bezpośrednich, i to pomimo że systemy prawne państw członkowskich w zdecydowanej większości są już dostosowane do stawianych przez nie obostrzeń. Jest to szczególnie istotne $\mathrm{w}$ związku z zasadniczo niekwestionowaną regułą nadrzędności regulacji unijnych nad krajowymi porządkami prawnymi, a co za tym idzie - możliwością skutecznego powoływania się na te regulacje przed sądami poszczególnych państw członkowskich w przypadku wystąpienia jednak pewnych sprzeczności pomiędzy tymi uregulowaniami.

Widać więc, że przepisy regulujące opodatkowanie SE są jednocześnie regulacjami odnoszącymi się do innych spółek kapitałowych (np. spółki akcyjnej)

${ }^{15}$ Dz. U. z 2009 r. Nr 160, poz. 1268 ze zm.

${ }_{16}$ B. Brzeziński (red.), Model Konwencji OECD. Komentarz, Warszawa 2010, s. 488-538. 
w poszczególnych państwach. Chociaż jest wielu zwolenników takiego stanu rzeczy, warto zastanowić się, czy opodatkowanie SE nie powinno odznaczać się jakimiś odrębnościami prawnopodatkowymi.

Warto w tym miejscu podkreślić, że argumenty o neutralności prawa podatkowego i szczególnym uprzywilejowaniu wybranych spółek nie miały zastosowania do holdingów. Mimo że holdingi nie posiadają (zarówno w Polsce, jak i w większości państw UE) ustawowej definicji ani innej regulacji ich sankcjonującej, występują rozwiązania podatkowe, które przeznaczone są wyłącznie dla holdingów (grup kapitałowych). W Polsce przykładem takiego rozwiązania jest podatkowa grupa kapitałowa ${ }^{17}$. Głównym założeniem podatkowej grupy kapitałowej jest możliwość natychmiastowego pokrywania strat jednych spółek grupy z dochodów innych. Według zasad ogólnych podatkowe rozliczenie strat spółki z zyskami innego podmiotu możliwe byłoby przez kolejne 5 lat podatkowych, w równych częściach. Korzyść utworzenia grupy polega więc na szybkim i pełnym rozliczeniu straty powstałej w spółce wchodzącej w skład grupy.

Inną istotną zaletą podatkowych grup jest unikanie zagrożenia podwójnego opodatkowania w razie nieodpłatnego przenoszenia własności składników majątku między spółkami tworzącymi grupę.

Kolejna ważna korzyść wynika z istniejących powiązań pomiędzy spółkami grupy, które mogą oddziaływać na kształtowanie wzajemnych stosunków. Chodzi tu o stosowanie cen odbiegających od rynkowych lub zawieranie umów pomiędzy podmiotami o nieodpłatne świadczenia, które nie powodują konsekwencji podatkowych. Spółki, które nie tworzą podatkowej grupy, lecz wykorzystują określone powiązania pomiędzy sobą, narażone są na korektę osiąganych zysków i ponoszonych strat oraz na sankcyjny podatek ${ }^{18}$.

Bardzo istotny jest również fakt, że dywidendy wypłacane w ramach grupy są neutralne podatkowo.

Podobne rozwiązania występują również w innych państwach UE. W Holandii jest to fiscale eenheid, w Hiszpanii - regimen de declaration consolidada, we Francji - regime de l'integration fiscale, zwane również groupes de societes, w Wielkiej Brytanii - group relief, capital gains group, group income, w Niemczech - Organschaft, w Danii - sambeskatning ${ }^{19}$.

Warto podkreślić, że w stosunku do tych rozwiązań nie padły zarzuty, że holdingi krajowe są uprzywilejowane w odróżnieniu od opodatkowania samodzielnie spółek kapitałowych, które tworzą ten właśnie holding. Nie można więc zgodzić się z argumentem, że dyskryminowane są pod względem podatkowym spółki, które nie wchodzą w skład podatkowej grupy kapitałowej. Wydaje się za-

17 Art. 1a u.p.d.o.p.

${ }^{18}$ D. Gajewski, Opodatkowanie holdingów i grup kapitałowych, Warszawa 2005, s. 160-165.

${ }^{19}$ H. Litwińczuk, Opodatkowanie koncernów. Rozwiązania w państwach Unii Europejskiej, „Przegląd Podatkowy” 1995, nr 3, s. 18-23. 
tem, że potrzebne są rozwiązania podatkowe uwzględniające specyfikę i międzynarodowy charakter SE.

4. Nową koncepcją, która jest aktualnie przedmiotem zaawansowanych prac, jest koncepcja wprowadzenia do europejskiego prawa podatkowego nowego, mającego mieć zastosowanie do europejskich typów spółek, modelu opodatkowania ich dochodu. Koncepcja ta określana jest mianem Wspólnej Skonsolidowanej Korporacyjnej Podstawy Opodatkowania (Common Consolidated Corporate Tax Base, CCCTB $)^{20}$. Rozwiązanie takie miałoby, po pierwsze, uatrakcyjnić tworzenie SE, a po drugie, stanowić próbę przeciwdziałania możliwym nadużyciom, dla których ewentualną podstawę mogą stanowić nie do końca ścisłe regulacje europejskiego prawa podatkowego.

Koncepcja CCCTB jest obecnie najbardziej zaawansowaną koncepcją harmonizacji opodatkowania spółek w UE. Podstawowym celem prawa wspólnotowego jest zniesienie przeszkód w funkcjonowaniu rynku wewnętrznego. Obecnie nie ma regulacji podatkowych, które pozwalałyby na prowadzenie działalności grupie spółek na terytorium więcej niż jednego państwa członkowskiego. Podstawa opodatkowania dla spółek wchodzących w skład takiej grupy jest ustalana zgodnie z zasadami przyjętymi w państwie, w którym każda z tych spółek ma siedzibę. Problemem jest wskazanie, jaka część globalnego dochodu grupy powinna być przypisana danej spółce w państwie jej siedziby, zwłaszcza w kontekście skomplikowanych zasad i procedur dotyczących cen transferowych ${ }^{21}$.

Koncepcja CCCTB polega na tym, że spółka mogłaby obliczać podstawę opodatkowania (dochód) według zasad obowiązujących w kraju jej siedziby. Następnie taki dochód byłby dzielony proporcjonalnie pomiędzy kraje działalności spółki i opodatkowany tam według lokalnej stawki.

Rozwiązania CCCTB obejmują zakresem podmiotowym, oprócz grupy spółek, także wszystkie spółki spełniające warunki formalne dotyczące rezydencji podatkowej i formy prawnej. Spółki te będą mogły dokonać wyboru pomiędzy podstawą krajową a koncepcją CCCTB. W przypadku, gdy wybiorą CCCTB, jako indywidualni podatnicy będą ustalać swoją podstawę opodatkowania według wspólnych reguł określonych w dyrektywie. Tak więc koncepcja CCCTB ma charakter opcjonalny i jej zastosowanie należy do decyzji samych podatników ${ }^{22}$.

${ }^{20}$ Szerzej o tej koncepcji: M. Lang et al. (red.), Common Consolidated Corporate Tax Base, Wiedeń 2008; W. Schon, U. Schreiber, Ch. Spengel, A Common Consolidated Corporate Tax Base for Europe, Heidelberg 2008; M. Supera-Markowska, Wspólna skonsolidowana podstawa opodatkowania jako koncepcja harmonizacji opodatkowania korporacyjnego w UE, Warszawa 2010; H. Litwińczuk, Wspólna korporacyjna Podstawa Opodatkowania w UE a opodatkowanie dochodu spółek w Polsce, Warszawa 2011.

${ }^{21}$ H. Litwińczuk, Wspólna korporacyjna podstawa opodatkowania w UE - analiza wybranych elementów konstrukcyjnych, [w:] Prawo finansowe w warunkach czlonkostwa Polski w Unii Europejskiej, Lublin 2011, s. 257.

${ }^{22}$ Ibidem, s. 258. 
Taki wybór będzie miał sens, jeżeli reguły wynikające z koncepcji CCCTB będą korzystniejsze niż rozwiązania podatkowe funkcjonujące w poszczególnych państwach UE.

Dochód w koncepcji CCCTB zdefiniowano jako różnicę pomiędzy przychodami i kosztami ich uzyskania. Warto jednocześnie zauważyć, że bardzo szeroka definicja przychodu obejmuje przychody nie tylko z bieżącej działalności gospodarczej, lecz także przychody z działalności o charakterze inwestycyjnym (zyski kapitałowe, dywidendy, odsetki, należności licencyjne). Tak szeroka koncepcja przychodu lepiej odzwierciedla zdolność podatkową, a także umożliwia pokrywanie kosztów czy strat z działalności inwestycyjnej z przychodami z bieżącej działalności gospodarczejej ${ }^{23}$.

Oceniając koncepcję CCCTB jako zespół wspólnych reguł ustalania podstawy opodatkowania, powinno się jej dokonywać przez pryzmat krajowej podstawy opodatkowania. Porównanie krajowej podstawy opodatkowania i CCCTB będzie prowadziło do wniosku, które rozwiązanie jest korzystniejsze dla samych podatników.

Jeżeli CCCTB zostałaby wprowadzona w UE, to przedsiębiorcy działający w formach spółek prawa europejskiego uzyskaliby możliwość m.in. łatwiejszego rozwiązywania problemów z cenami transferowymi czy potrącania straty podatkowej wynikającej z działalności na obszarze Wspólnoty. Ponadto, CCCTB zminimalizowałaby ryzyko wprowadzenia niezgodnych z prawem UE ograniczeń podstawowych swobód wspólnego rynku.

Opisywana tu koncepcja jednolitego modelu opodatkowania europejskich typów spółek nie jest jednak pozbawiona słabych stron. Wprowadzenie takiego rozwiązania w życie mogłoby się wiązać z zarzutami naruszenia zakazu dyskryminacji oraz nakazu równego traktowania SE z jednej strony, a przedsiębiorców prowadzących działalność gospodarczą w innych formach prawnych - z drugiej.

Wraz z koncepcją CCCTB forsowana jest koncepcja zmierzająca do stopniowego ujednolicania podstawy opodatkowania dla wszystkich podmiotów prowadzących działalność gospodarczą w więcej niż jednym państwie Wspólnoty. Koncepcja CCCTB budzi jednak opór grupy państw, w których obowiązują niskie stawki podatku CIT (np. Słowacja, Litwa, Wielka Brytania), obawiających się ujednolicenia w przyszłości stawek tego podatku, a co za tym idzie - likwidacji zjawiska konkurencji podatkowej pomiędzy systemami prawnymi członków UE.

\footnotetext{
${ }^{23}$ Ibidem, s. 262.
} 